\title{
Kewenangan Otoritas Jasa Keuangan (OJK) Melakukan Penyidikan: Analisis Pasal 9 Huruf C Undang-Undang Nomor 21 Tahun 2011 Tentang Otoritas Jasa Keuangan
}

\author{
Serlika Aprita* \\ Fakultas Hukum Universitas Muhammadiyah Palembang \\ *Correspondence email: 5312lika@gmail.com
}

\begin{abstract}
Abstrak. Dalam Undang-Undang No. 21 Tahun 2011 tentang Otoritas Jasa Keuangan memberikan kewenangan kepada OJK untuk melakukan penyidikan. Penyidikan merupakan salah satu tugas pengawasan OJK seperti yang disebut dalam Pasal 9 huruf c UU OJK yang berbunyi: "Untuk melaksanakan tugas pengawasan sebagaimana dimaksud dalam Pasal 6, OJK mempunyai wewenang melakukan pengawasan, pemeriksaan, penyidikan, perlindungan Konsumen, dan tindakan lain terhadap Lembaga Jasa Keuangan, pelaku, dan/atau penunjang kegiatan jasa keuangan sebagaimana dimaksud dalam peraturan perundang-undangan di sektor jasa keuangan." Menurut Pasal Pasal 49 ayat (1) Undang-Undang No 21 Tahun 2011 tentang Otoritas Jasa Keuangan (OJK) Penyidik OJK adalah: 1. Selain Pejabat Penyidik Kepolisian Negara Republik Indonesia, Pejabat Pegawai Negeri Sipil tertentu yang lingkup tugas dan tanggung jawabnya yang meliputi pengawasan sektor jasa keuangan di lingkungan OJK, diberi wewenang khusus sebagai penyidik sebagaimana dimaksud dalam Kitab Undang-Undang Hukum Acara Pidana. Adapun metode penelitian dalam penulisan ini adalah menggunakan penelitian hukum normatif. Pengaturan mengenai peranan OJK sebagai Penyidik dalam diatur dalam pasal 9 huruf (c) Undang-Undang No. 20 Tahun 2011 tentang Otoritas Jasa Keuangan yang menjadi landasan bagi OJK dalam melakukan penyidikan tindak pidana perbankan, sehingga OJK melaksanakan fungsi penyelenggaraan sistem pengaturan dan pengawasan yang terintegrasi terhadap keseluruhan kegiatan di sektor jasa keuangan
\end{abstract}

Kata Kunci: Otoritas Jasa Keuangan; Penyidikan; Pengawasan; Lembaga Jasa Keuangan

Abstract. In Law No. 21 of 2011 concerning the Financial Services Authority authorizes the OJK to carry out investigations. Investigation is one of OJK's supervisory duties as referred to in Article 9 letter $c$ of the OJK Law which reads: "To carry out the supervisory duties as referred to in Article 6, OJK has the authority to carry out supervision, examination, investigation, consumer protection, and other actions against Service Institutions. Finance, actors and / or supporting financial services activities as referred to in the laws and regulations in the financial services sector. "According to Article 49 paragraph (1) of Law No. 21 of 2011 concerning Financial Services Authority (OJK), OJK Investigators are: 1. Apart from Investigating Officers of the State Police of the Republic of Indonesia, certain Civil Servants whose scope of duties and responsibilities includes supervision financial services sector within the OJK, given special authority as investigators as referred to in the Criminal Procedure Code. The research method in this paper is to use normative legal research. The regulation regarding the role of the OJK as an investigator is regulated in article 9 letter (c) of Law No. 20 of 2011 concerning the Financial Services Authority which becomes the basis for OJK in conducting investigations of banking crimes, so that the OJK carries out the function of implementing an integrated regulatory and supervisory system of all activities in the financial services sector.

Keywords: Financial Services Authority; Investigation; Supervision; Financial Services Institutions

\section{PENDAHULUAN}

Berdasarkan tujuan nasional yang tertuang di dalam alinea keempat Pembukaan UUD NRI Tahun 1945 yaitu membentuk suatu pemerintahan negara Indonesia yang melindungi segenap bangsa Indonesia dan seluruh tumpah darah Indonesia dan untuk memajukan kesejahteraan umum. Dalam rangka mewujudkan tujuan tersebut, maka perlu adanya pembangunan nasional. Pembangunan nasional dilakukan dari, oleh dan untuk rakyat dan serta dilaksanakan di dalam segala aspek kehidupan bangsa yang meliputi aspek hukum, ekonomi, politik, sosial budaya dan aspek pertahanan dan keamanan. ${ }^{1}$
Bank Indonesia dalam posisinya sebagai Lembaga Tinggi Negara adalah stake holder yang memiliki posisi yang sangat strategis dalam mendukung pembangunan nasional dalam hal perekonomian negara baik dalam melayani pemerintahan negara maupun dunia keuangan dan perbankan di Indonesia, Posisi Bank Sentral sebagai Lembaga Tinggi Negara yang berwenang untuk melakukan pengawasan dan melakukan fungsi regulasi terhadap kebijakan moneter sebuah negara, adalah aspek penting dalam tercapainya cita-cita stabilitas ekonomi pada sebuah negara. Stabilitas ekonomi yang kemudian berujung pada tercapainya cita-cita bernegara dalam upaya mendorong terciptanya general welfare dilakukan

${ }^{1}$ Hermansyah, Hukum Perbankan Nasional Indonesia, Jakarta:Kencana, 2005, hlm.9. 
dengan mengoptimalkan fungsi pengawasan dari Bank Sentral, dalam hal ini Bank Indonesia. ${ }^{2}$

Pemerintah melalui otoritas keuangan dan perbankan, dalam hal ini Bank Indonesia berwenang menetapkan aturan dan bertanggungjawab melakukan pengawasan terhadap jalannya usaha dan aktivitas perbankan. Oleh karenanya, kebijakan pemerintah disektor perbankan harus diarahkan kepada upaya mewujudkan perbankan yang sehat, kuat dan kokoh. Pemerintah telah cukup memberikan perhatian kepada penyempurnaan peraturan-peraturan hukum di bidang perbankan, namun demikian kelengkapan peraturan saja tidak cukup untuk dijadikan ukuran bahwa perbankan nasional harus lepas dari segala permasalahan. ${ }^{3}$

Keadaan suatu bank dikatakan sebagai bank bermasalah sehingga membahayakan kelangsungan usahanya apabila berdasarkan penilaian Bank Indonesia, kondisi usaha bank semakin memburuk, antara lain, menurunnya permodalan, kualitas aset, likuiditas, dan rehabilitas, serta pengelolaan bank yang tidak dilakukan berdasarkan prisip kehati-hatian dan asas perbankan yang sehat. Bank yang mengalami masalah berat dan akhirnya menjadi bank yang tidak sehat, biasanya dimulai dengan terjadinya mismatch, yaitu ketidakcocokan dallam pengelolaan dana disisi aktiva dan sisi passiva. Apabila kredit yang dikeluarkan menjadi non performing, artinya kredit tidak kembali tepat waktu, maka bank mengalami kesulitan mencari dana pengganti untuk dibayarkan kepada deposan. Bila usaha bank mencari dana tersebut tidak berhasil,maka ada dua kemungkinan yang akan terjadi sebagai berikut:

1. Bank akan di-rush oleh nasabahnya (deposan) sebab tidak terjadinya pembayaran kepada nasabah pemilik dana, artinya runtuhnya kepercayaan nasabah bank,maka dananya ditarik kembali;

2. Bank akan menyerahkan diri kepada Bank Indonesia sebagai "lender of last resort"dan meminta bantuan likuiditas BLBI. Bank juga dapat melakukan lobi politik meminta bantuan pemerintah untuk turun tangan. Keppres Nomor 26 Tahun 1998 memberikan blanket guaratee berupa BLBI kepada semua bank agar terhindar dari rush.

Dalam hal suatu bank mengalami permasalahan yang dapat membahayakan kelangsungan usahanya, maka berdasarkan ketentuan Pasal 37 ayat (1) UndangUndang Nomor 10 Tahun 1998 tentang Perbankan menyatakan bahwa Bank Indonesia mempunyai tanggungjawab hukum yaitu melakukan tindakan agar:

1. Pemegang saham menambah modal

${ }^{2}$ Kasmir, Bank dan Lembaga Keuangan Lainnya, Jakarta: RajawaliPress, 2008, hlm.77.

${ }^{3}$ Ade Arthesa dan Edia Handiman, Bank dan Lembaga Keuangan Bukan Bank, Jakarta: PT. Indeks Kelompok Gramedia, 2010, hlm.50.
2. Pemegang saham mengganti dewan komisaris dan atau direksi bank;

3. Bank menghapusbukukan kredit atau pembiayaan berdasarkan prinsip syariah yang macet dan memperhitungkan kerugian bank dengan modalnya;

4. Bank melakukan merger atau konsolidasi dengan bank lain;

5. Bank dijual kepada pembeli yang bersedia mengambil alih seluruh kewajiban;

6. Bank menyerahkan pengelolaan seluruh atau sebagian kegiatan bank kepada pihak lain;

7. Bank menjual sebagian atau seluruh harta dan/atau kewajiban bank kepada bank atau pihak lain. ${ }^{4}$

Langkah-langkah yang telah dilakukan oleh Bank Indonesia terhadap bank-bank bermasalah sebagai bentuk tanggungjawab hukum dalam upaya untuk menghindari terjadinya pencabutan izin usahanya dan/atau likuidasi. Tetapi, apabila tindakan yang dimaksud dalam Pasal 37 ayat 1 belum cukup mengatasi kesulitan bank maka,berdasarkan ketentuan Pasal 37 ayat 2 huruf b Undang-Undang Nomor 10 Tahun 1998 tentang Perubahan atas Undang-Undang Nomor 7 Tahun 1992 tentang Perbankan menyatakan bahwa apabila menurut penilaian Bank Indonesia keadaan suatu bank membahayakan sistem Perbankan, pimpinan Bank Indonesia dapat mencabut izin usaha bank dan memerintahkan Direksi bank untuk segera menyelenggarakan Rapat Umum Pemegang Saham guna membubarkan badan hukum bank dan membentuk tim. Berdasarkan ketentuan pasal ini menunjukkan bahwa apabila tidak dilakukan pencabutan dan pembubaran atas bank yang bermasalah tersebut, maka akan membahayakan sistem perbankan.

Kriteria membahayakan sistem perbankan yaitu apabila tingkat kesulitan yang dialami dalam melakukan kegiatan usaha, suatu bank tidak mampu memenuhi kewajiban-kewajibannya kepada bank lain, sehingga pada gilirannya akan berdampak kepada bank-bank lain. Apabila Direksi bank tidak menyelenggarakan Rapat Umum Pemegan Saham terkait pencabutan izin dan pembubaran bank,maka pimpinan Bank Indonesia meminta kepada pengadilan untuk mengeluarkan penetapan yang berisi pembubaran badan hukum bank, penunjukkan tim likuidasi, dan perintah pelaksanaan likuidasi sesuai dengan peraturan perundang-undangan yang berlaku. ${ }^{5}$

Tanggung jawab hukum Bank Indonesia terhadap bank-bank bermasalah sebagaimana dijelaskan dalam ketentuan Pasal 37 huruf a Undang-Undang Nomor 10 Tahun 1998 tentang Perbankan, maka atas permintaan Bank Indonesia, pemerintah setelah berkonsultasi

\footnotetext{
${ }^{4}$ Rachmawadi Usman, Aspek-Aspek Hukum Perbankan di Indonesia, Jakarta:Gramedia Pustaka Utama, 2001, hlm.13.

${ }^{5}$ Rudi Tri Santoso, Mengenai Dunia Perbankan, Yogyakarta:ANDI, 1997, hlm.90.
} 
kepada Dewan Perwakilan Rakyat Republik Indonesia dapat membentuk badan khusus yang bersifat sementara dalam upaya penyehatan perbankan. Badan khusus yang dimaksud dalam ketentuan ini bersifat sementara sampai dengan selesainya tugas yang diberikan kepada badan ini yaitu:

1. Penyehatan bank yang diserahkan oleh Bank Indonesia;

2. Penyelesaian aset bank baik aset fisik maupun kewajiban debitor melalui Unit Pengelola Aset (Asset Management Unit);

3. Pengupayaan pengembalian uang negara yang telah tersalur kepada bank-bank. ${ }^{6}$

Berdasarkan ketentuan pasal ini terlihat adanya peranan langsung dari pemerintah untuk menanggulanginya melalui kebijakan dan tindakan yang berdampak pada Anggaran Pendapatan dan Belanja Negara. Tindakan-tindakan yang dilakukan oleh Bank Indonesia terhadap bank-bank bermasalah merupakan bentuk tanggungjawab hukum Bank Indonesia dalam upaya mempertahankan bank sebagai lembaga kepercayaan masyarakat, dimana apabila Bank Indonesia tidak melakukan tindakan-tindakan diatas akan membahayakan keadaan perekonomian nasional yang berdampak kepada hajat hidup orang banyak.

Salah satu faktor yang membuat sistem perbankan nasional keropos adalah akibat perilaku pengelola dan pemilik bank yang cenderung mengeksploitasi dan atau mengabaikan prinsip kehati-hatian dalam berusaha. Disamping faktor penunjang lain yaitu lemahnya kontrol pengawasan pemerintah melalui Bank Indonesia. Sentral, dalam melakukan fungsi pengawasan terhadap bank-bank yang ada di Indonesia diatur di dalam Pasal 8 huruf (c) Undang-Undang Nomor 3 Tahun 2004 Tentang Perubahan Atas Undang-Undang Nomor 23 Tahun 1999 Tentang Bank Indonesia, yang selanjutnya disebut sebagai Undang-Undang Bank Indonesia.

Sejalan dengan amanat Pasal 34 Undang-Undang Nomor 3 Tahun 2004 Tentang Perubahan Atas UndangUndang Nomor 23 Tahun 1999 Tentang Bank Indonesia adalah dibentuknya lembaga pengawas pada jasa keuangan yang dengan lahirnya Undang-Undang Nomor 21 Tahun 2011 Tentang Otoritas Jasa Keuangan. Dengan lahirnya lembaga Otoritas Jasa Keuangan, maka peran serta Bank Indonesia sebagai lembaga pengawasan Bank beralih kepada lembaga Otoritas Jasa Keuangan (selanjutnya disebut dengan OJK). Berdasarkan ketentuan Pasal 1 angka 1 Undang-Undang Nomor 21 Tahun 2011 tentang Otoritas Jasa Keuangan menyatatakan bahwa OJK merupakan lembaga yang independen dan bebas dari campur tangan pihak lain, yang mempunyai tugas, fungsi, tugas, dan wewenang

${ }^{6}$ Gunarto Suhardi, Usaha Meningkatkan Kinerja dan Kepatuhan Perbankan di Indonesia, Yogyakarta:Universitas Atmajaya Yogyakarta, 2004, hlm.3. pengaturan, pengawasan, pemeriksaan, dan penyidikan sebagaimana dimaksud dalam undang-undang ini".

Berdasarkan ketentuan pasal diatas menunjukkan bahwa pengertian OJK sebagaimana diatur dalam Pasal 1 Undang-Undang Nomor 21 Tahun 2011 tentang Otoritas Jasa Keuangan menunjukkan bahwa Otoritas Jasa Keuangan adalah sebuah lembaga pengawasan jasa keuangan seperti industri perbankan, pasar modal, reksadana, perusahaan pembiayaan, dana pensiun dan asuransi. Pada dasarnya Undang-Undang tentang OJK ini hanya mengatur mengenai pengorganisasian dan tata pelaksanaan kegiatan keuangan dari lembaga yang memiliki kekuasaan. ${ }^{7}$

Lembaga Otoritas Jasa Keuangan (OJK) telah didirikan dengan Undang-Undang Nomor 21 tahun 2011 akan diberlakukan mulai tahun 1 Januari 2013, dengan tugas untuk mengawasi lembaga keuangan baik bank maupun non bank. Lembaga ini didirikan sesuai dengan amanat Pasal 34 Undang-Undang Nomor 23 tahun 1999 tentang Bank Indonesia. Sesuai dengan bunyi Pasal 34 tersebut bahwa yang dialihkan adalah tugas pengawasan bank.

Dengan diberlakukannya OJK, maka fungsi dan wewenang Bank Indonesia semakin sempit. Sementara tujuan tunggalnya tetap sama yaitu mencapai dan memelihara kestabilan nilai rupiah. Memelihara kestabilan rupiah ini terhadap dua aspek yakni kestabilan rupiah terhadap harga barang dan kestabilan rupiah terhadap nilai tukar dengan mata uang negara asing (valas). Itulah tujuan tunggal Bank Indonesia (single objective). Dengan tujuan tunggal tersebut, Bank Indonesia selama ini mempunyai 3 (tiga) tugas yakni sektor moneter, sistem pembayaran dan sektor perbankan. Itulah tiga pilar penopang tujuan tunggal, namun dengan dilepaskannya sektor perbankan, kini tinggal dua sektor. Bila diibaratkan 3 pilar, maka 1 pilar telah patah. ${ }^{8}$

Bank Indonesia setelah hak untuk melakukan pengawasan dipindahkan kepada otoritas jasa keuangan, maka untuk mencapai tujuan tersebut OJK memiliki fungsi untuk menyelenggarakan sistem pengaturan dan pengawasan yang terintegrasi terhadap keseluruhan kegiatan didalam sektor jasa keuangan. ${ }^{9}$ Pengaturan dan pengawasan OJK dilakukan terhadap(a) kegiatan jasa keuangan di sektor perbankan; (b) kegiatan jasa keuangan di sektor pasar modal; (c)kegiatan jasa keuangan di sektor perasuransian, dana pensiun, lembaga pembiayaan, dan lembaga jasa keuangan

${ }^{7}$ Ketentuan Pasal 1 Undang-Undang Nomor 21 Tahun 2011 tentang Otoritas Jasa Keuangan

${ }^{8}$ AbdulkadirMuhammad dan Rilda Muniarti, Segi Hukum Lembaga Keuangan dan Pembiayaan, Edisi Revisi, Bandung:PT.Citra Aditya Bakti, 2004, hlm.35.

${ }^{9}$ Ketentuan Pasal 5 Undang-Undang Nomor 21 Tahun 2011 tentang Otoritas Jasa Keuangan. 
lainnya. ${ }^{10}$ Selanjutnya untuk melaksanakan tugas dan pengaturan dalam menjalankann perannnya sebagaiaman diatur dalam ketentuan Pasal 6 Undang-Undang Nomor 21 Tahun 2011 tentang Otoritas Jasa Keuangan, maka OJK memiliki wewenang untuk:

1. Pengaturan dan pengawasan mengenai kelembagaan bank yang meliputi:

a. perizinan untuk pendirian bank, pembukaan kantor bank, anggaran dasar, rencana kerja, kepemilikan, kepengurusan dan sumber daya manusia, merger, konsolidasi dan akuisisi bank, serta pencabutan izin usaha bank; dan

b. kegiatan usaha bank, antara lain sumber dana, penyediaan dana, produk hibridasi, dan aktivitas di bidang jasa;

2. Pengaturan dan pengawasan mengenai kesehatan bank yang meliputi:

a. likuiditas, rentabilitas, solvabilitas, kualitas aset, rasio kecukupan modal minimum, batas maksimum pemberian kredit, rasio pinjaman terhadap simpanan, dan pencadangan bank;

b. laporan bank yang terkait dengan kesehatan dan kinerja bank;

c. sistem informasi debitur;

d. pengujian kredit (credit testing); dan

e. standar akuntansi bank;

3. pengaturan dan pengawasan mengenai aspek kehatihatian bank, meliputi:

a. manajemen risiko;

b. tata kelola bank;

c. prinsip mengenal nasabah dan anti pencucian uang; dan

d. pencegahan pembiayaan terorisme dan kejahatan perbankan; dan

e. pemeriksaan bank. ${ }^{11}$

Untuk melaksanakan tugas pengaturan sebagaimana dimaksud dalam Pasal 6, OJK mempunyai wewenang:

1. menetapkan peraturan pelaksanaan Undang-Undang ini;

2. menetapkan peraturan perundang-undangan di sektor jasa keuangan;

3. menetapkan peraturan dan keputusan OJK;

4. menetapkan peraturan mengenai pengawasan di sektor jasa keuangan;

5. menetapkan kebijakan mengenai pelaksanaan tugas OJK;

6. menetapkan peraturan mengenai tata cara penetapan perintah tertulis terhadap Lembaga Jasa Keuangan dan pihak tertentu;

\footnotetext{
${ }^{10}$ Ketentuan Pasal 6 Undang-Undang Nomor 21 Tahun 2011 tentang Otoritas Jasa Keuangan.

${ }^{11}$ Pasal 7 Undang-Undang Nomor 21 Tahun 2011 tentang Otoritas Jasa Keuangan.
}

7. menetapkan peraturan mengenai tata cara penetapan pengelola statuter pada Lembaga Jasa Keuangan;

8. menetapkan struktur organisasi dan infrastruktur, serta mengelola, memelihara, dan menatausahakan kekayaan dan kewajiban; dan

9. menetapkan peraturan mengenai tata cara pengenaan sanksi sesuai dengan ketentuan peraturan perundangundangan di sektor jasa keuangan. ${ }^{12}$

Untuk melaksanakan tugas pengawasan sebagaimana dimaksud dalam Pasal 6, OJK mempunyai wewenang:

1. menetapkan kebijakan operasional pengawasan terhadap kegiatan jasa keuangan;

2. mengawasi pelaksanaan tugas pengawasan yang dilaksanakan oleh Kepala Eksekutif;

3. melakukan pengawasan, pemeriksaan, penyidikan, perlindungan Konsumen, dan tindakan lain terhadap Lembaga Jasa Keuangan, pelaku, dan/atau penunjang kegiatan jasa keuangan sebagaimana dimaksud dalam peraturan perundang-undangan di sektor jasa keuangan;

4. memberikan perintah tertulis kepada Lembaga Jasa Keuangan dan/atau pihak tertentu;

5. melakukan penunjukan pengelola statuter;

6. menetapkan penggunaan pengelola statuter;

7. menetapkan sanksi administratif terhadap pihak yang melakukan pelanggaran terhadap peraturan perundang-undangan di sektor jasa keuangan; dan

8. memberikan dan/atau mencabut:
a. izin usaha;
b. izin orang perseorangan;
c. efektifnya pernyataan pendaftaran;
d. surat tanda terdaftar;
e. persetujuan melakukan kegiatan usaha;
f. pengesahan;
g. persetujuan atau penetapan pembubaran; dan
h. penetapan lain. ${ }^{13}$

Berdasarkan ketentuan Pasal 9 huruf (e) dan (f) Undang-Undang 21 Tahun 2011 tentang Otoritas Jasa Keuangan menyatakan bahwa untuk melaksanakan tugas pengawasan, OJK berwenang satu diantranya adalah untuk melakukan penunjukkan pengelola statuter dan menetapkan penggunaan pengelola statuter. Pengelola statuter merupakan perorangan atau badan hukum yang ditunjuk oleh OJK untuk mengelola suatu bank yang dalam pengawasan OJK. Jadi pengelola statuter ini menggantikan peran dari direksi.

Sejalan dengan fungsi dan kewenangannya untuk melakukan penunjukkan pengelola statuter dan menetapkan penggunaan pengelola statuter

\footnotetext{
${ }^{12}$ Pasal 8 Undang-Undang Nomor 21 Tahun 2011 tentang Otoritas Jasa Keuangan.

${ }^{13}$ Pasal 9 Undang-Undang Nomor 21 Tahun 2011 tentang Otoritas Jasa Keuangan.
} 
menunjukkan bahwa OJK sebagai lembaga pengawas baru yang akan mempunyai tugas dan beban strategis kelembangaan yang berat atau superbody, jelas memiliki indepedensi yang tinggi dalam menjalankan kewenangannya. Hal tersebut dimaksudkan agar setiap regulasi dan pengawasan yang dilakukan oleh OJK benar-benar bersifat objektif, tanpa dipengaruhi intervensi pihak manapun dan mencehag terjadinya benturan kewenangan dan kepentingan antara berbagai faktor yang berinteraksi dalam menjalankan kewenangannya tersebut. ${ }^{14}$

Dasar hukum lahirnya OJK adalah Pasal 34 Undang-Undang Nomor 8 Tahun 2004 tentang Bank Indonesia menyatakan bahwa tugas mengawasi bank akan dilakukan oleh lembaga indepeden. Istilah pengawasan dalam bahasa Indonesa asal katanya adalah "awas", sehingga pengawasan merupakan kegiatan mengawasi saja, dalam arti melihat sesuat dengan seksama. Tidak ada kegiatan dilauar itu kecuali melaporkan hasil pengawasan. ${ }^{15}$

OJK diharapkan dapat memberikan perlindungan hukum dalam bentuk pengawasan yang lebih baik dengan melakukan fungsi pengawasan secara maksimal terhadap menyelenggarakan sistem pengaturan dan pengawasan yang terintegrasi terhadap keseluruhan kegiatan didalam sektor jasa keuangan sebagaimana telah diatur dalam Undang-Undang Nomor 21 Tahun 2011 tentang Otoritas Jasa Keuangan. Adanya pengaturan mengenai pengawasan yang dilakukan oleh OJK dalam bentuk perlindungan hukum sebagaimana diatur dan dijelaskan dalam peraturan perundangundangan menunjukkan bahwa hak asasi manusia dalam hal ini pihak-pihak yang berkaitan dengan kegiatan dalam sektor jasa keuangan telah diatur secara prosedural, sehingga fungsi hukum untuk melindungi masyarakat dan individu terhadap perbuatan-perbuatan yang mengganggu tata tertib masyarakat yang dilakukan oleh individu-individu lain atau pemerintah sendiri (penyalahgunaan wewenang yang dilakukan oleh para petugas negara) maupun pemerintah asing (agresi atau subversi yang dilakukan pemerintah asing) dapat terpenuhi. ${ }^{16}$ Hal ini diperkuat dengan pendapat Roscue Pond yang mengemukakan bahwa hukum untuk melindungi kepentingan manusia (law as tool of social engineering), dikarenakan kepentingan manusia adalah

${ }^{14}$ Nova Asmirawati, Catatan Singkat Terhadap Undang-Undang Nomor 21 Tahun 2011 tentang Otoritas Jasa Keuangan, Jurnal Legislasi Indonesia, Vol.9. No.3, 2012, hlm.5

${ }^{15}$ Victor Situmorang dan Jusuf Juhir, Aspek Hukum Pengawasan Melekat dalam Lingkungan Aparatur Pemerintah, Jakarta:Rineka Cipta,1994, hlm.17.

${ }^{16}$ E.Utrecht dan Moh. Saleh Djindang, "Pengantar dalam Hukum Indonesia”, Jakarta:PT Ichtiar Baru, Anggota IKAPI dan Penerbit Sinar Harapan, 1989, hlm.15 suatu tuntutan yang dilindungi dan dipenuhi manusia dalam bidang hukum. ${ }^{17}$

Meningkatnya tingkat kebutuhan masyarakat dalam hal menyelenggarakan sistem pengaturan dan pengawasan yang terintegrasi terhadap keseluruhan kegiatan didalam sektor jasa keuangan, kondisi ini apabila tidak dibarengi dengan fungsi pengawasan yang terintegritas dari OJK akan mengakibatkan kerugian dalam kegiatan di sektor jasa keuangan. Berkaitan dengan fungsi pengawasan yang dimiliki OJK maka, berdasarkan ketentuan Pasal 9 Undang-Undang Nomor 21 Tahun 2011 tentang OJK menyatakan bahwa untuk melaksanakan tugas pengawasan sebagaimana dimaksud dalam Pasal 6, OJK mempunyai wewenang satu diantaranya adalah melakukan penunjukkan pengelola statuter dan menetapkan penggunaan pengelolaan statuter.

Pengertian pengelola statuter dalam kaitannya dengan ketentuan Pasal 9 huruf (e) dan (f) UndangUndang Nomor 12 Tahun 2011 tentang Otoritas Jasa Keuangan adalah perorangan atau badan hukum yang ditunjuk oleh OJK untuk mengelola suatu bank yang berada dalam pengawasan OJK. OJK adalah lembaga yang independen dan bebas dari campur tangan pihak lain, yang mempunyai fungsi, tugas, dan wewenang pengaturan, pengawasan, pemeriksaan, dan penyidikan. OJK didirikan untuk menggantikan peran Bapepam-LK dalam pengaturan dan pengawasan pasar modal dan lembaga keuangan, dan menggantikan peran Bank Indonesia dalam pengaturan dan pengawasan bank, serta untuk melindungi pihak-pihak kegiatan didalam sektor jasa keuangan, konsumen industri jasa keuangan.

Berbagai konsep pengertian perlindungan hukum juga ditemukan pada berbagai peraturan perundangundangan, satu diantaranya pengertian perlindungan hukum menurut Undang-Undang Nomor 40 Tahun 1999 tentang Pers menyatakan bahwa perlindungan hukum adalah jaminan perlindungan pemerintah dan atau masyarakat kepada warga negara dalam melaksanakan fungsi, hak, kewajiban dan peranannya sesuai dengan ketentuan peraturan perundang-undangan yang berlaku.

Berdasarkan ketentuan Undang-Undang Nomor 23 tahun 2004 tentang Penghapusan Kekerasan dalam Rumah Tangga menyatakan bahwa:

"perlindungan adalah segala upaya yang ditujukan
untuk memberikan rasa aman kepada korban yang
dilakukan oleh pihak keluarga, advokat, lembaga
sosial, kepolisian, kejaksaan, pengadilan, atau pihak
lainnya baik sementara maupun berdasarkan
penetapan pengadilan"

Berdasarkan pengertian perlindungan hukum diatas menunjukkan bahwa fungsi pengawasan yang

${ }^{17}$ Salim HS, Perkembangan Teori dalam Ilmu Hukum, Jakarta:Rajawali Pers, 2010, hlm.41-42. 
dimiliki OJK sebagaimana diatur dalam Undang-Undang Nomor 21 Tahun 2011 tentang OJK bertujuan untuk melindungi pihak-pihak yang berkepentingan dalam kegiatan di sektor jasa keuangan. Konsumen pengguna jasa keuangan dimana dalam hal ini dalam kegiatan di sektor jasa keuangan perusahaan pembiayaan konsumen merupakan pihak yang perlu mendapatkan perlindungan hukum yang maksimal dari OJK, dikarenakan konsumen rentan akan perbuatan yang merugikan kedudukannya dalam perjanjian antara konsumen dan perusahaan pembiayaan konsumen. Satu diantaranya adalah pencantuman klausula baku yang seringkali dilakukan oleh perusahaan pembiayaan konsumen. Adanya pencantuman klausula baku inilah yang menjadi salah satu alasan utama diperlukan adanya pengawasan OJK terhadap perusahaan pembiayaan konsumen.

Ciri utama dari klausula baku adalah sifat uniform atau keseragaman dari syarat-syarat perjanjian untuk semua perjanjian untuk sifat yang sama. Syarat-syarat baku dalam perjanjian adalah syarat-syarat konsep tertulis yang dimuat dalam beberapa perjanjian yang masih dimuat, yang jumlahnya tidak tertentu dan tanpa merundingkan dahulu isinya. ${ }^{18}$

Pembentukkan Undang-Undang Nomor 21 Tahun 2011 tentang OJK dapat dijadikan landasan hukum bagi konsumen yang dirugikan atas perbuatan perusahaan pembiayaan. Dikarenakan didalam peraturan perundangundangan tersebut berisikan sekumpulan aturan hukum yang bersifat memaksa, yang menentukan tingkah laku manusia dalam lingkungan masyarakat yang dibuat oleh badan-badan resmi yang berwajib, pelanggaran mana terhadap peraturan-peraturan tadi mengakibatkan diambilnya tindakan, yaitu dengan hukuman tertentu hal ini sebagaimana pengertian hukum menurut J.C.T. Simorangkir dan Woerjono Sastropranoto. ${ }^{19}$

Bentuk perlindungan hukum yang diberikan oleh OJK terhadap konsumen pengguna jasa keuangan dalam hal ini perusahaan pembiayaan konsumen dalam kegiatan di sektor jasa keuangan sebagaimana diatur dalam Undang-Undang Nomor 21 Tahun 2011 tentang OJK menunjukkan bahwa perlindungan yang diberikan kepada konsumen telah memenuhi suatu gambaran dari fungsi hukum yaitu konsep dimana hukum dapat memberikan suatu keadilan, ketertiban, kepastian, kemanfaatan dan kedamaian. ${ }^{20}$

Dengan adanya OJK sebagai pengganti fungsi pengawasan oleh Bank Indonesia diharapkan agar kegiatan pada perusahaan pembiayaan mampu

${ }^{18}$ Purwahid Patrik, "Peranan Perjanjian Baku dalam Masyarakat", Makalah, dalam seminar Standar Kontrak dalam Perjanjian Kredit, Surabaya, 11 Desember 1993, hlm.1.

${ }^{19}$ C.S.T Kansil, "Pengantar Ilmu Hukum dan Tata Hukum Indonesia”, Jakarta:Balai Pustaka, 1989, hlm.38.

$$
{ }^{20} \text { Pengertian Perlindungan Hukum, }
$$

http://www.prasko.com/2011/02/pengertian-perlindungan-

hukum.html, dikases pada 14 Juni 2015. melindungi kepentingan konsumen dengan cara terpenuhinya hak-hak konsumen, hal ini sebagaimana dijelaskan Fitzgerald bahwa hukum melindungi kepentingan seseorang dengan cara mengalokasikan kekuasaan kepadanya secara terukur untuk bertindak dalam rangka kepentingannya yang disebut dengan hak. Keperluan hukum adalah mengurusi hak dan kepentingan manusia, sehingga hukum memiliki otoritas tertinggi untuk menentukan kepentingan manusia yang perlu dilindungi dan diatur yang tertuang dalam bentuk peraturan. ${ }^{21}$

Adanya pengaturan mengenai bentuk perlindungan hukum yang diberikan OJK kepada konsumen pada perusahaan pembiayaan konsumen dalam Undang-Undang Nomor 21 Tahun 2011 tentang OJK menunjukkan bahwa OJK dalam melaksanakan fungsi pengawasannya mengutamakan hak asasi konsumen sebagai bentuk perlindungan hukum, hal ini sebagaimana dijelaskan oleh Satjipto Rahardjo, perlindungan hukum adalah memberikan pengayoman terhadap hak asasi manusia yang dirugikan orang lain dan perlindungan itu diberikan kepada masyarakat agar dapat menikmati semua hak-hak yang diberikan oleh hukum. ${ }^{22}$

Secara filosofi perlindungan hukum bermuara pada suatu bentuk kepastian hukum yang diberikan oleh Pemerintah. Kepastian hukum oleh aliran yuridis dogmatis dipandang sebagai ilmu hukum positif. Tujuan hukum dititik beratkan pada segi kepastian hukumnya, yang cenderung melihat hukum sebagai suatu yang mandiri. Penganut pemikiran ini, hukum tidak lain hanya kumpulan aturan yang tidak lain dari sekedar menjamin terwujudnya kepastian hukum. Oleh karena yang dibiayai adalah barang untuk tujuan konsumtif, sudah tentu mengandung resiko tersebut yang menyebar pada banyak konsumen dengan pembiayaan yang relatif kecil dan rate of interest yang tinggi. Bagi perusahaan pembiayaan konsumen keadaan ini masih aman, tetapi masih tetap diperlukan jaminan dari pihak konsumen dalam kegiatan di sektor jasa keuangan. ${ }^{23}$

Dengan adanya fungsi pengawasan yang dilakukan OJK terhadap lembaga pembiayaan konsumen diharapkan dapat memberikan perlindungan hukum bagi konsumen pengguna lembaga ini yaitu masyarakat dalam memenuhi kebutuhan barang-barang dengan mencicil yang dibarengi dengan meningkatnya taraf kehidupan masyarakat lapisan menengah kebawah serta membantu mengatasi kendala-kendala dari masyarakat yang berpenghasilan rendah dalam kegiatan di sektor jasa keuangan.

${ }^{21}$ J.HAL. Fitzgerald, dalam Satjipto Rahardjo, "Ilmu Hukum”, Bandung:PT. Citra Aditya Bakti, 2000, hlm.69.

${ }^{22}$ Satjipto Rahardjo, "Ilmu Hukum" , Bandung:PT. Citra Aditya Bakti, 2000, hlm. 53.

${ }^{23}$ Munir Fuady, "Hukum tentang Lembaga Pembiayaan", Bandung:Citra Aditya Bakti, 1999, hlm.162. 
Pembentukan Otoritas Jasa Keuangan (OJK) di Indonesia didasari dari keinginan pemerintah dalam melakukan regulasi baru dalam hal pengawasan perbankan yang dianggap mulai mengalami kelemahan. Kedudukan OJK yang menjadi lembaga yang independen dan memiliki kewenangan yang cukup luas dan tegas dalam pengawasan perbankan diharapkan dapat memperbaiki permasalahan yang saat ini timbul di bidang pengawasan perbankan. Dengan besarnya kedudukan dan kewenangan yang dimiliki oleh lembaga yang satu ini, tentunya harus ada suatu pengaturan yang jelas dan tertulis demi mewujudkan kepastian hukum. Lembaga OJK yang dulunya sudah terbentuk masih belum memiliki suatu pengaturan yang jelas. Namun dengan dilahirkan Undang-Undang Nomor 21 Tahun 2011 Tentang Otoritas Jasa Keuangan memberikan kepastian hukum, dan undang-undang tersebut menjadi dasar hukum dalam melaksanakan kewajiban dan kewenangan dari lembaga tersebut.

Menurut Jimly Asshiddiqie, welfare state dalam perundang-undangan untuk pertama kalinya dikenal dengan istilah "negara pengurus". Negara pengurus dalam konsep negara kesejahteraan berarti terdapat tanggung jawab negara untuk mengembangkan kebijakan negara di berbagai bidang kesejahteraan sebagai wujud dalam pelaksanaan fungsi pelayanan umum (publik service) melalui penyediaan intervensiintervensi pemerintah. Karakter negara kesejahteraan menempatkan lembaga yang bertugas mewujudkan kesejahteraan rakyat. Kedudukan unsur pemerintah tidak harus selalu dipandang bertentangan secara diametral dengan kedudukan rakyat seperti didalam negara hukum liberal dan negara hukum formal. Adapun pandangan negara kesejahteraan terhadap pemerintah jauh lebih bersahabat daripada negara hukum formal. Pemerintah tidak dianggap sebagai lawan melainkan sebagai rekan kerja dalam mencapai tujuan kesejahteraan umum. Namun kewenangan bertindak lembaga-lembaga pemerintah atas inisiatif sendiri dalam negara kesejahteraan menunjukkan suatu proses perubahan pola pikir tujuan negara hukum negara kesejahteraan, dimana tujuan utama negara hukum kesejahteraan adalah kemanfaatan sedangkan tujuan negara hukum formal adalah kepastian hukum yang berdasarkan asas legalitas.

Uraian diatas menunjukkan hakikat independensi yang sesungguhnya yang merupakan abstraksi dari nilainilai yang digali dari perkembangan nilai yang ada didalam masyarakat suatu bangsa. Nilai-nilai tersebut adalah kedaulatan rakyat dalam pembentukan kebijaksanaan dan kebijakan bukan semata-mata karena kehendak penguasa atau pemerintah. Tetapi, pengaturan lembaga independen di Indonesia tidak menunjukkan hakikat independensi yang sesungguhnya sebab lembaga independen yang diatur dalam undang-undang tertentu dikenakan teori yang digunakan di negara Indonesia adalah negara hukum materil atau negara hukum berdimensi pelayanan politik. ${ }^{24}$ Sehingga, dalam melayani rakyatnya, pemerintah turut serta dalam menentukan kebijaksanaan (wisdom) dan kebijakan (policy) yang berorientasi pada kepentingan pemerintah dalam berbagai bidang khususnya dalam kegiatan ekonomi yang tidak diserahkan sepenuhnya kepada rakyat, melainkan dilibatkannya partisipasi pemerintah. Seperti yang ada didalam pengaturan lembaga independen didalam Undang-Undang Nomor 21 Tahun 2011 tentang Otoritas Jasa Keuangan yang melibatkan peran serta Kemenkeu (Koordinator FKSSK) sebagai wakilnya Pemerintah Republik Indonesia.

Setiap pihak dilarang campur tangan terhadap pelaksanaan tugas dan wewenang OJK dengan maksud bahwa untuk menjamin terselenggaranya pengaturan dan pengawasan sektor jasa keuangan yang optimal dan mampu meningkatkan daya saing nasional, maka OJK harus dapat bekerja secara independen dalam peraturan perundang-undangan di bidang jasa keuangan. Oleh karena itu, sesuai dengan Pasal 2 ayat (2) UndangUndang Nomor 21 Tahun 2011 tentang Otoritas Jasa Keuangan, dalam melaksanakan tugas dan wewenangnya, OJK bebas dari campur tangan pihak lain. Sebagai pengamat ekonomi, Imam Sugema mengatakan bahwa OJK pada prinsipnya pengawasan regulasi untuk berbagai lembaga keuangan mulai bank, asuransi, multi finance, kemudian pasar modal, bursa berjangka, pengaturan dan supervisinya disatukan, OJK sebagai regulatornya. ${ }^{25}$

Tentang kewenangan penyidikan yang dipunyai oleh penyidik OJK ini, seperti penyidikan terhadap semua tindak pidana yang menyangkut jasa keuangan seperti diatur dalam sektor perbankan, pasar modal, perasuransian, dana pensiun, lembaga pembiayaan. Sementara terhadap tindak pidana perbankan telah ada penyidik sebelumnya yaitu pejabat Polisi Negara, Jaksa dan KPK.5 Wewenang baru yang diemban oleh OJK sesuai dengan Undang - Undang nomor 21 tahun 2011 pasal 9 ayat 3 adalah melakukan penyidikan. Berbeda dengan Bank Indonesia selama ini yang punya wewenang dalam pengawasan bank, namun tidak memiliki kewenangan penyidikan, sebatas melakukan investigasi kalau menemukan dugaan terjadinya tindak pidana. Kewenangan penyidikan sendiri meliputi kewenangan untuk :

1. Menerima laporan, pemberitahuan, atau pengaduan dari seseorang tentang adanya tindak pidana di sektor jasa keuanagan.

${ }^{24}$ Anggito Abimanyu, Tantangan OJK, Ringkasan Makalah yang Disampaikan Kepada Pansel OJK, ditulis tanggal 08 April 2012.

${ }^{25}$ Arsip Dokumen Dewan Perwakilan Rakyat Republik Indonesia,Risalah Sidang Pembentukan Otoritas Jasa Keuangan, Jakarta, 2010. 
2. Melakukan penelitian atas kebenarnya laporan atau keterangan berkenaan dengan tindak pidana di sektor jasa keuangan.

3. Melakukan penelitian terhadap setiap orang yang diduga melakukan atau terlibat dalam tindak pidana di sektor jasa keuangan.

4. Memanggil, memeriksa, serta meminta keterangan dan barang bukti dari setiap orang yang disangka melakukan, atau sebagai saksi dalam tindak pidana di sektor jasa keuangan.

5. Melakukan pemeriksaan atas pembukuan, catatan, dan dokumen lain berkenaan dengan tindak pidana di sektor jasa keuangan.

6. Melakukan penggeledahan di setiap tempat tertentu yang diduga terdapat setiap barang bukti pembukuan, pencatatan, dan dokumen lain serta melakukan penyitaan terhadap barang yang dapat dijadikan bahan bukti dalam perkara tindak pidana di sektor jasa keuangan.

7. Meminta data, dokumen, alau alat bukti lain, baik cetak maupun elektronik kepada penyelenggara jasa telekomunikasi.

8. Dalam keadaan tertentu meminta kepada pejabat yang berwenang untuk melakukan pencegahan terhadap orang yang diduga telah melakukan tindak pidana di sektor jasa keuangan sesuai dengan ketentuan peraturan perundang - undangan.

9. Meminta bantuan aparat penegak hukum lain.

10. Meminta keterangan dari bank tentang keadaan keuangan pihak yang diduga melakukan atau terlibat dalam pelanggaran terhadap peraturan perundangundangan di sektor jasa keuangan.

11.Memblokir rekening pada bank atau lembaga keuangan lain dari pihak yang diduga melakukan atau terlibat dalam tindak pidana di sektor jasa keuangan.

12. Meminta bantuan ahli dalam rangka pelaksanaan tugas penyidikan tindak pidana di sektor jasa keuangan

13. Menyatakan saat dimulai dan dihentikannya penyidikan.

Di bidang pidana kejaksaan mempunyai tugas dan wewenang melakukan penyidikan terhadap tindak pidana tertentu berdasarkan undang - undang. Jadi apabila terindikasi adanya tindak pidana korupsi di sektor jasa keuangan (sektor perbankan dan lain-lain) maka Jaksa berwenang melakukan penyidikan. Begitu juga penyidik KPK, selaku penyidik mempunyai kewenangan penyidikan terhadap tindak pidana korupsi, seperti diatur dalam Undang-Undang Nomor 30 Tahun 2002 tentang Komisi Pemberantasan Korupsi Pasal 6 . Komisi Pemberantasan Korupsi mempunyai tugas : Melakukan penyelidikan, penyidikan dan penuntutan terhadap tindak pidana korupsi.

\section{METODE \\ Jenis Penelitian}

Jenis penelitian ini adalah penelitian hukum normatif. Di dalam buku Teori dan Metode Penelitian Hukum Normatif, karangan Johny Ibrahim, mengatakan bahwa "penelitian hukum normatif adalah prosedur penelitian ilmiah untuk menemukan kebenaran berdasarkan logika keilmuan hukum dari sisi normatifnya. Logika keilmuan dalam penelitian hukum normatif dibangun berdasarkan disiplin ilmiah dan cara kerja ilmu hukum normatif"26. Kemudian pendapat ini didukung oleh Peter Mahmud Marzuki yang menjelaskan bahwa penelitian hukum adalah suatu proses untuk menemukan aturan hukum, prinsip-prinsip hukum, maupun doktrin-doktrin hukum guna menjawab isu hukum yang akan dihadapi. Hal ini sesuai dengan karakter preskiptif ilmu hukum. Berbeda dengan penelitian yang dilakukan di dalam keilmuan yang bersifat deskriptif yang menguji kebenaran ada tidaknya suatu fakta disebabkan oleh suatu faktor tertentu, penelitian hukum dilakukan untuk menghasilkan argumentasi, teori atau konsep baru sebagai preskipsi dalam menyelesaikan masalah yang dihadapi ${ }^{27}$. Lebih lanjut Bambang Waluyo, dalam bukunya Penelitian Hukum dalam Praktek, mengatakan bahwa "penelitian ini merupakan suatu kegiatan ilmiah yang didasarkan pada metode, sistematika dan pemikiran tertentu yang bertujuan untuk mempelajari suatu hukum tertentu dengan jalan menganalisanya" 28

Jenis penelitiani adalah penelitian hukum normatif preskriptif, yang menurut Peter Mahmud Marzuki adalah penelitian hukum yang bertujuan untuk mempelajari tujuan hukum, nilai-nilai keadilan, validitas aturan hukum, konsep-konsep hukum, dan norma-norma hukum. ${ }^{29}$ Penelitian tesis menurut Peter Mahmud Marzuki dilakukan untuk menghasilkan argumentasi, teori, atau konsep baru sebagai preskripsi dalam menyelesaikan masalah yang dihadapi. ${ }^{30}$ Argumentasi disini dilakukan untuk memberikan preskriptif mengenai benar atau tidaknya menurut hukum terhadap fakta atau peristiwa hukum dari hasil penelitian.

Penelitian ini dimaksudkan untuk melakukan pengkajian mengenai kaidah-kaidah, konsep hukum, doktrin dan norma yang berkaitan dengan dengan kewenangan Otoritas Jasa Keuangan (OJK) dalam mengangkat pengelola statuter: analisis Pasal 9 huruf (e)

\footnotetext{
${ }^{26}$ Johny Ibrahim, Teori dan Metode Penelitian Hukum Normatif. Malang: Bayumedia, 2006, hlm.47.

${ }^{27}$ Peter Mahmud Marzuki, Penelitian Hukum, Jakarta: Prenada Media,2005, hlm.35.

${ }^{28}$ Bambang Waluyo, Penelitian Hukum dalam Praktek. Jakarta: Sinar Grafika, 1996, hlm.8.

${ }^{29}$ Peter Mahmud Marzuki, "Penelitian Hukum", Kencana, Jakarta, 2010, hlm.22.

${ }^{30} \mathrm{Ibid}$
} 
dan (f) Undang-Undang Nomor 21 Tahun 2011 tentang Otoritas Jasa Keuangan.

\section{Pendekatan Penelitian}

Pendekatan yang dipakai adalah pendekatan filsafat (philosophical approach), pendekatan perundang-undangan (statue approach), pendekatan kasus (case approach), pendekatan sejarah (history approach) dan pendekatan yang akan datang (futuristic approach)

\section{Pendekatan Filsafat (Philosophical Approach)}

Pendekatan filsafat akan mengkaji isu hukum (legal issue) dalam penelitian normatif dan mengkajinya secara mendalam. ${ }^{31}$ Pendekatan filsafat digunakan untuk kewenangan Otoritas Jasa Keuangan (OJK) dalam mengangkat pengelola statuter: analisis Pasal 9 huruf (e) dan (f) Undang-Undang Nomor 21 Tahun 2011 tentang Otoritas Jasa Keuangan.

\section{Pendekatan Perundang-Undangan (Statue Approach)}

Suatu penelitian normatif harus menggunakan pendekatan perundang-undangan dan yang akan diteliti adalah berbagai aturan hukum yang menjadi fokus utama sekaligus tema sentral suatu penelitian. Menurut Peter Mahmud Marzuki pendekatan perundang-undangan dalam kegiatan akademisi peneliti perlu mencari ratio legis dan dasar ontologis lahirnya undang-undang tersebut. Pendekatan ini digunakan untuk memperoleh deskripsi analisis permasalahan hukum yang terkait dengan kewenangan Otoritas Jasa Keuangan (OJK) dalam mengangkat pengelola statuter: analisis Pasal 9 huruf (e) dan (f) Undang-Undang Nomor 21 Tahun 2011 tentang Otoritas Jasa Keuangan

Pendekatan Perundang-Undangan (statute approach) dilakukan dengan menelaah Undang-Undang Nomor 21 Tahun 2011 tentang Otoritas Jasa Keuangan dan regulasi yang bersangkut paut dengan isu hukum yang dikaji. Hasil dari telaah tersebut merupakan suatu argumen untuk memecahkan isu yang dihadapi. ${ }^{32}$

\section{Pendekatan Kasus (Case Approach)}

Pendekatan kasus dilakukan dengan cara melakukan telaah terhadap kasus-kasus yang berkaitan dengan isu yang sedang dihadapi yang telah menjadi putusan pengadilan yang telah mempunyai kekuatan tetap. Dalam mempergunakan pendekatan kasus peneliti harus memahami ratio decidendi yaitu alasan-alasan hukum yang digunakan hakim untuk sampai kepada putusannya. ${ }^{33}$

\footnotetext{
${ }^{31}$ Johhny ibrahim, "Teori dan Metode Penelitan Hukum Normatif”, Malang:Bayumedia, 2006,hlm.267.

${ }^{32}$ Peter Mahmud Marzuki, "Penelitian Hukum Normatif”, Jakarta:Kencana, 2010, hlm. 93.

${ }^{33}$ Peter Mahmud Marzuki,Op.Cit.,hlm.119.
}

Dalam tesis ini menggunakan pendekatan kasus yaitu kasus mengenai kewenangan Otoritas Jasa Keuangan (OJK) dalam mengangkat pengelola statuter: analisis Pasal 9 huruf (e) dan (f) Undang-Undang Nomor 21 Tahun 2011 tentang Otoritas Jasa Keuangan.

\section{Pendekatan Sejarah (History Approach)}

Sejarah hukum berusaha mengenali dan memahami secara sistematis proses-proses terbentuknya hukum, faktor-faktor yang menyebabkan dan sebagainya serta memberi tambahan yang pengetahuan yang berharga untuk memahami fenomena hukum dalam masyarakat ${ }^{34}$. Pendekatan ini digunakan untuk mengetahui latar belakang dari pembentukan UndangUndang Nomor 21 Tahun 2011 tentang Otoritas Jasa Keuangan.

\section{Pendekatan yang akan Datang (Futuristic Approach)}

Merupakan penelitian hukum yang menyangkut pembangunan hukum di masa depan (futuristic atau antisipatoris) sehingga diperlukan metode penelitian sosial atau metode penelitian sosio legal. Dengan demikian kegiatan-kegiatan seperti ini merupakan kegiatan yang interdisipliner. ${ }^{35}$

Dalam tesis ini menggunakan pendekatan yang akan datang (futuristic approach) mengenai pengaturan hukum yang ideal dan riil dalam mendukung kewenangan Otoritas Jasa Keuangan (OJK) dalam mengangkat pengelola statuter: analisis Pasal 9 huruf (e) dan (f) Undang-Undang Nomor 21 Tahun 2011 tentang Otoritas Jasa Keuangan dalam peraturan perundangundangan Otoritas Jasa Keuangan pada masa depan.

\section{Jenis dan Sumber Bahan-Bahan Hukum}

Jenis dan sumber bahan-bahan hukum yang digunakan dalam penelitian tesis ini ada tiga macam mengacu kepada tata cara penyusunan sumber bahanbahan hukum menurut Soerjono Soekanto, maka bahan hukum primer, bahan hukum sekunder, dan bahan hukum tersier, dalam penelitian ini meliputi:

\section{Bahan Hukum Primer}

Bahan hukum primer, yaitu bahan-bahan hukum yang mengikat dan terdiri dari ${ }^{36}$ :

1. Undang-Undang Dasar 1945.

2. Kitab Undang-Undang Hukum Perdata.

\footnotetext{
${ }^{34}$ Jhonny Ibrahim, Op. Cit., hlm. 256

${ }^{35}$ Diah Nabila, "Pertimbangan Hukum Hakim dalam Menentukan Keabsahan Akta Notaris sebagai Pejabat Pembuat Akta Tanah tentang Akta Jual Beli Hak atas Tanah", Tesis, Program Magister Kenotariatan Fakultas Hukum Universitas Sriwijaya, Palembang, 2012, dalam http://notariat.fh.unsri.ac.id/mkn/index.php/posting/35, diakses pada 28 Februari 2013.

${ }^{36}$ C.F.G. Sunaryati Hartono, "Penelitian Hukum di Indonesia Pada Akhir Abad Ke-2”, PT.Alumni, Bandung, 1994, hlm.134.
} 
Serlika Aprita, Kewenangan Otoritas Jasa Keuangan (OJK) Melakukan Penyidikan: Analisis Pasal 9 Huruf C Undang-Undang Nomor 21 Tahun 2011 Tentang Otoritas Jasa Keuangan

3. Undang-Undang Nomor 10 Tahun 1998 tentang Perbankan.

4. Undang-Undang Nomor 8 Tahun 2004 tentang Bank Indonesia.

5. Undang-Undang Nomor 21 Tahun 2011 tentang Otoritas Jasa Keuangan.

\section{Bahan Hukum Sekunder}

Bahan hukum sekunder adalah bahan yang memberikan penjelasan mengenai bahan hukum primer terdiri dari ${ }^{37}$ :

1. Literatur-literatur yang berkaitan dengan permasalahan.

2. Makalah yang berkaitan dengan permasalahan.

3. Hasil karya ilmiah pakar hukum

4. Pendapat pakar hukum

\section{Bahan Hukum Tersier}

Bahan hukum tersier adalah bahan yang memberikan petunjuk maupun penjelasan terhadap bahan hukum primer dan sekunder, seperti kamus (hukum) dan ensiklopedia. ${ }^{38}$

\section{Teknik Pengumpulan dan Pengklasifikasian Bahan Hukum}

Pengumpulan bahan-bahan hukum dilakukan dengan pengelompokkan peraturan perundangundangan, meneliti bahan pustaka, membaca buku-buku dan sumber-sumber lainnya yang berhubungan dengan permasalahan dalam penelitian ini. ${ }^{39}$ Setelah memperoleh bahan-bahan hukum dari hasil penelitian kepustakaan, maka dilakukan pengolahan bahan-bahan hukum dengan cara mengadakan sistematisasi terhadap bahanbahan hukum tertulis. Sistematisasi berati membuat klasifikasi terhadap bahan-bahan hukum untuk memudahkan pekerjaan analitis dan konstruksi. ${ }^{40}$

\section{Teknik Pengolahan Bahan-Bahan Hukum}

Teknik pengolahan bahan-bahan hukum dilakukan dengan menggunakan inventarisasi dan sistematisasi terhadap peraturan perundang-undangan yang ada relevansinya dengan pengaturan hukum mengenai kepailitan. setelah memperoleh bahan-bahan hukum dari hasil penelitian kepustakaan maka, dilakukan pengolahan bahan-bahan hukum yang didapatkan dengan cara mengadakan sistematisasi terhadap bahanbahan hukum tertulis. Sistematisasi berarti membuat

\footnotetext{
${ }^{37}$ Bambang Waluyo, "Penelitian Hukum Dalam Praktek", Sinar Grafika, Jakarta, 1999, hlm.7-8.

${ }^{38}$ Soerjono Soekanto, "Pengantar Penelitian Hukum", Jakarta:UI Press, 2007, hlm.52.

${ }^{39}$ Soerjono dan Abdurrahman, "Metode Penelitian Hukum.”, Jakarta:Rineka Cipta, 1997, hlm.56.

${ }^{40}$ Soejono Soekanto dan Sri Mamudji,"Penelitian Hukum Normatif Suatu Tinjauan Singkat", Jakarta:PT. Raja Grafindo Persada, 2002, hlm.251.
}

klasifikasi terhadap bahan-bahan hukum untuk memudahkan pekerjaan analitis dan konstruksi. ${ }^{41}$

\section{Teknik Analisis Penelitian}

Analisis yang dilakukan dalam penelitian ini melalui penafsiran hukum dan konstruksi hukum terhadap analisis bahan-bahan hukum yang telah dikumpulkan dan diolah. Mengolah dan menganalisis bahan-bahan hukum tidak lepas dari berbagai penafsiran yang dikenal dalam ilmu hukum. Penafsiran hukum antara lain:

Adapun penafsiran hukum terdiri atas:

1. Penafsiran gramatikal ialah menafsirkan undangundang menurut arti perkataan hal ini memberikan pengertian bahwa terdapat hubungan yang erat antara bahasa yang dipergunakan sebagai satu-satunya alat yang dipergunakan pembuat undang-undang untuk menyatakan kehendak sesuai dengan bahasa seharihari atau bahasa hukum. ${ }^{42}$

2. Penafsiran sistematis ialah penafsiran dengan cara memperhatikan adanya hubungan antara satu pasal dengan pasal lain dalam suatu undang-undang.

3. Penafsiran autentik ialah penafsiran yang diberikan oleh pembentuk undang-undang.

Selain penafsiran hukum, ada kontruksi hukum yang membantu dalam menganalisis bahan-bahan hukum. Metode konstruksi hukum yang digunakan dalam penelitian ini, antara lain:

1. Metode penyempitan/pengkonkritan hukum (rechtsvervijnings), metode ini bertujuan untuk meyempitkan/mengkonkritkan suatu aturan hukum yang terlalu abstrak, luas, dan umum, sehingga dapat diterapkan terhadap suatu peristiwa tertentu ${ }^{43}$.

2. Fiksi hukum, bermaksud untuk mengatasi konflik antara tuntutan-tuntutan baru dengan aturan-aturan yang $\operatorname{ada}^{44}$

\section{Teknik Penarikan Kesimpulan}

Penarikan kesimpulan dalam tesis ini menggunakan metode deduktif yaitu dengan cara pengambilan kesimpulan dari pembahasan yang bersifat umum menjadi kesimpulan yang bersifat khusus, sehingga dapat mencapai tujuan yang diinginkan yaitu menjawab rumusan. ${ }^{45}$ Dengan menggunakan metode ini maka aturan-aturan hukum yang bersifat umum dijabarkan dalam wujud aturan-aturan hukum konkret, sehingga dapat ditafsirkan dan disimpulkan aturan-

\footnotetext{
${ }^{41}$ Soerjono Soekanto, Op.Cit., hlm.251

${ }^{42}$ Mochtar Kusumaatmadja, "Pengantar Ilmu Hukum", Alumni, Bandung, 2000, hlm.100.

43 Ibid., hlm. 61

${ }^{44}$ Ibid., hlm. 63

${ }^{45}$ Amiruddin dan Zainal Asikin, "Pengantar Metode Penelitian Hukum.”, PT RajaGrafindo Persada, Jakarta, 2003, hlm.18.
} 
aturan hukum khusus tentang kewenangan Otoritas Jasa Keuangan (OJK) dalam mengangkat pengelola statuter: analisis Pasal 9 huruf (e) dan (f) Undang-Undang Nomor 21 Tahun 2011 tentang Otoritas Jasa Keuangan dalam peraturan perundang-undangan Otoritas Jasa Keuangan.

\section{HASIL DAN PEMBAHASAN}

\section{Fungsi, Tugas, dan Kewenangan Otoritas Jasa} Keuangan Menurut Undang-undang Nomor 21 Tahun 2011

Undang- undang Nomor 21 Tahun 2011 tentang Otoritas Jasa keuangan merupakan payung hukum atau landasan hukum berdirinya Otoritas Jasa Keuangan atau OJK dalam melakukan kerjanya. Berdasarkan UndangUndang tersebut maka ditetapkan tujuan dibentuknya OJK secara eksplisit disebutkan dalam Pasal 4 bahwa dibentuknya OJK agar keseluruhan kegiatan di dalam sektor jasa keungan:

1. Terselenggaranya secara teratur, adil, transparan dan akuntabel;

2. Mampu mewujudkan system keuangan yang tumbuh secara berkelanjutan dan stabil;

3. Mampu melindungi kepentingan konsumen dan masyarakat. Tujuan otoritas jasa keuangan yang pertama, yakni agar keseluruhan kegiatan didalam sector jasa keuangan terselenggara secara teratur adil transparan dan akuntabel merupakan asas-asas yang terkandung dalam substansi hukum OJK.

Asas-asas tersebut ditemukan lebih lanjut dalam penjelasan umum atas Undang-Undang Nomor 21 Tahun 2011, sebagai berikut :

1. Asas Independensi, yakni independen dalam pengambilan keputusan dan pelaksanaan fungsi tugas dan wewenang OJK. Dengan tetap sesuai dengan peraturan perundang-undangan yang berlaku.

2. Asas kepastian hukum, yakni asas dalam Negara hukum yang mengutamakan landasan peraturan perundangundangan dan keadilan dalam setiap kebijakan penyelenggaraan OJK.

3. Asas kepentingan umum, yakni asas yang membela dan melindungi kepentingan konsumen dan masyarakat serta memajukan kesejahteraan umum.

4. Asas keterbukaan, yakni asas yang membuka diri terhadap hak masyarakat untuk memperoleh informasi yang benar jujur dan tidak diskriminatif tentang penyelenggaraan OJK dengan tetap memperhatikan perlingungan atas hak asasi pribadi dan golongan serta rahasia Negara termasuk rahasia sebagaimana ditetapkan dalam peraturan perundangundangan.

5. Asas profesionalitas, yakni asas yang mengutamakan keahlian dalam pelaksanaan tugas dan wewenang OJK dengan tetap berlandasakan pada kode etik dan ketentuan peraturan perundangundangan.
6. Asas integritas, yakni asas yang berpegang teguh pada nilai-nilai moral dalam setiap tindakan dan keputusan yang diambil dalam penyelenggaraan OJK.

7. Asas akuntabilitas, yakni asas yang menetukan bahwa setiap kegiatan Dan hasil akhir dari setiap kegiatan penyelenggaraan OJK harus dapat dipertanggungjawabkan kepada publik.

Untuk mencapai tujuan Otoritas Jasa keuangan Undang-Undang Nomor 21 Tahun 2011 telah mengatur pula terkait tugas, fungsi dan wewenang OJK terlebih khusus dalam bidang pencegaha dan pengawasan terhadap pendirian perusahaan invesatasi ilegal. UndangUndang Nomor 21 Tahun 2011 dalam Pasal 5 menyebutkan bahwa OJK berfungsi menyelenggarakan system pengaturan dan pengawasan yang terintegrasi terhadap keseluruhan kegiatan didalam sector jasa keuangan. Fungsi OJK tersebut bertolak dari sistem integrasi terhadap keseluruhan kegiatan didalam sector jasa keuangan melalui pengaturan dan pengawasan. Ruang lingkup OJK yang mencakup banyak bidang yang juga disebut sebagai sub system atau sub sector seperti perbankan, perasuransian, investasi dan lain-lainnya membutuhkan tata kendali yang terpusat untuk terintegrasinya aspek hukum dan kebijakan penyelenggaraan fungsi OJK.

\section{Tugas Otoritas Jasa Keuangan (OJK)}

Tugas secara umum OJK dalam UndangUndang Nomor 21 Tahun 2011 disebutkan pada Pasal 6 bahwa OJK yakni melaksanakan tugas pengaturan dan pengawasan terhadap :

1. Kegiatan jasa keuangan disektor perbankan;

2. Kegiatan jasa keuangan disektor pasar modal;

3. Kegiatan jasa keuangan disektor perasuransian, dana pensiun, lembaga pembiayaan dan lembaga jasa keuangan lainnya.

\section{Wewenang Otoritas Jasa Keuangan (OJK)}

Undang-undang Nomor 21 Tahun 2011 menjelaskan tentang kewenangan kewenangan OJK, salah satunya adalah kewengangan OJK dalam membuat peraturan-peraturan atau ketetapan-ketetapan, sebagai mana tertera pada pasal 8 OJK berwenang:

1. Menetapkan peraturan pelaksanaan Undang-Undang ini;

2. Menetapkan peraturan perundangundangan di sektor jasa keuangan;

3. Menetapkan peraturan dan keputusan OJK;

4. Menetapkan peraturan mengenai pengawasan di sektor jasa keuangan;

5. Menetapkan kebijakan mengenai pelaksanaan tugas OJK;

6. Menetapkan peraturan mengenai tata cara penetapan perintah tertuli terhadap Lembaga Jasa Keuangan dan pihak tertentu; 
7. Menetapkan peraturan mengenai tata cara penetapan pengelola statuter pada Lembaga Jasa Keuangan;

8. Menetapkan struktur organisasi dan infrastruktur, serta mengelola, memelihara, dan menatausahakan kekayaan dan kewajiban; dan

9. Menetapkan peraturan mengenai tata cara pengenaan sanksi sesuai dengan ketentuan peraturan perundangundangan di sektor jasa keuangan.

Huruf (d) pada pasal di atas menjelaskan bahwa OJK mempunyai wewenang membuat aturan-aturan mengenai kegiatan pengwasan yang di lakukan oleh OJK. Dengan demikian kekuatan Hukum OJK dalam melakukan pengawasan terhadap jasa keuangan sangatlah kuat. Dalam Undang-undang No 21 Tahun 2011 selain mengatur tentang kewenangan membuat peraturan, juga mengatur tentang wewenang OJK dalam melakukan pengawasan di dalam sektor jasa keuangan, yang terdapat dalam pasal 9, yaitu untuk melakukan tugas pengawasan:

1. Menetapkan kebijakan operasional pengawasan terhadap kegiatan jasa keuangan;

2. Mengawasi pelaksanaan tugas pengawasan yang dilaksanakan oleh Kepala Eksekutif

3. Melakukan pengawasan, pemeriksaan, penyidikan, perlindungan Konsumen, dan tindakan lain terhadap Lembaga Jasa Keuangan, pelaku, dan/atau penunjang kegiatan jasa keuangan sebagaimana dimaksud dalam peraturan perundangundangan di sektor jasa keuangan;

4. Memberikan perintah tertulis kepada Lembaga Jasa Keuangan dan/atau pihak tertentu

5. Melakukan penunjukan pengelola statuter;

6. Menetapkan penggunaan pengelola statuter;

7. Menetapkan sanksi administratif terhadap pihak yang melakukan pelanggaran terhadap peraturan perundang-undangan di sektor jasa keuangan; dan

8. Memberikan dan/atau mencabut : 1) Izin usaha; 2) Izin orang perseorangan; 3) Efektifnya pernyataan pendaftaran; 4) Surat tanda terdaftar; 5) Persetujuan melakukan kegiatan usaha; 6) Pengesahan; 7) Persetujuan atau penetapan pembubaran; dan 8) Penetapan lain, sebagaimana dimaksud dalam peraturan perundangundangan di sektor jasa keuangan.

\section{Peran Otoritas Jasa Keuangan Dalam Melakukan Penyidikan Terhadap Lembaga Jasa Keuangan}

Hal yang baru dalam UU OJK ini adalah bahwa OJK berwenang untuk melakukan penyidikan. Wewenang ini tidak dimiliki oleh Bank Indonesia sebagai pengawas bank selama ini. Wewenang yang lebih luas dalam konteks pemeriksaan ini seperti wewenang aparat penegak hukum. OJK dapat bertindak lebih tegas lagi apabila menemukan pelanggaran/penyelewengan dari hasil pemeriksaannya. Namun perlu diingat bahwa sebagaimana diuraikan di atas, industri perbankan adalah industri kepercayaan yang bersifat sistemik. Bagi institusi pengawas/pemeriksa perbankan punya tugas dilihat dari dua sisi.Sisi penegakan hukum/ketentuan dan sisi lain yakni agar perbankan nasional terus tumbuh dengan sehat, sehingga harus punya strategi agar apabila menemukan pelanggaran ibarat menangkap ikan, jangan sampai airnya keruh. Hal ini agak berbeda dengan aparat penegak hukum lainnya. Selain hal tersebut, anggaran operasional OJK akan dibiayai melalui APBN dan dipungut dari institusi yang diawasi (lembaga keuangan \& perbankan) (Pasal 37 UU OJK). Hal ini agak aneh, di satu sisi OJK diberi wewenang lebih luas (sampai proses penyidikan), di lain sisi biaya operasionalnya dapat dipungut dari institusi yang diawasi, sehingga dapat menimbulkan conflict of interest. Bagaimana pembuatan UU dapat terjadi seperti ini.

Wewenang baru yang diemban oleh OJK sesuai dengan pasal 9(c) adalah melakukan penyidikan. Berbeda dengan Bank Indonesia selama ini yang punya wewenang dalam pengawasan bank, namun tidak memiliki kewenangan penyidikan, sebatas melakukan investigasi kalau menemukan dugaan terjadinya tindak pidana. Kewenangan penyidikan sendiri meliputi kewenangan untuk: a. menerima laporan, pemberitahuan, atau pengaduan dari seseorang tentang adanya tindak pidana di sektor jasa keuangan; b. melakukan penelitian atas kebenaran laporan atau keterangan berkenaan dengan tindak pidana di sektor jasa keuangan; c. melakukan penelitian terhadap Setiap Orang yang diduga melakukan atau terlibat dalam tindak pidana di sektor jasa keuangan; d. memanggil, memeriksa, serta meminta keterangan dan barang bukti dari Setiap Orang yang disangka melakukan, atau sebagai saksi dalam tindak pidana di sektor jasa keuangan; e. melakukan pemeriksaan atas pembukuan, catatan, dan dokumen lain berkenaan dengan tindak pidana di sektor jasa keuangan; f. melakukan penggeledahan di setiap tempat tertentu yang diduga terdapat setiap barang bukti pembukuan, pencatatan, dan dokumen lain serta melakukan penyitaan terhadap barang yang dapat dijadikan bahan bukti dalam perkara tindak pidana di sektor jasa keuangan; g. meminta data, dokumen, atau alat bukti lain, baik cetak maupun elektronik kepada penyelenggara jasa telekomunikasi; $h$. dalam keadaan tertentu meminta kepada pejabat yang berwenang untuk melakukan pencegahan terhadap orang yang diduga telah melakukan tindak pidana di sektor jasa keuangan sesuai dengan ketentuan peraturan perundang-undangan; i. meminta bantuan aparat penegak hukum lain; $j$. meminta keterangan dari bank tentang keadaan keuangan pihak yang diduga melakukan atau terlibat dalam pelanggaran terhadap peraturan perundang-undangan di sektor jasa keuangan; $\mathrm{k}$. memblokir rekening pada bank atau lembaga keuangan lain dari pihak yang diduga melakukan atau terlibat dalam tindak pidana di sektor jasa keuangan; 1 . meminta 
bantuan ahli dalam rangka pelaksanaan tugas penyidikan tindak pidana di sektor jasa keuangan; dan $\mathrm{m}$. menyatakan saat dimulai dan dihentikannya penyidikan.

Wewenang penyidikan meliputi antara lain dapat langsung menggeledah dan menyita dokumen yang diperlukan serta menemukan, menangkap dan menahan tersangka.Namun mengingat OJK adalah lembaga independen yang dibentuk dengan Undang-Undang tersendiri, dimana pegawainya bukan termasuk Pegawai Negeri Sipil (PNS), maka apabila OJK melakukan penyidikan harus menggunkan/bekerja sama dengan PNS yang memiliki hak untuk melakukan penyidikan atau dengan POLRI. Hal ini juga membawa konsekuensi penyediaan anggaran OJK untuk keperluan ini.

Dengan diberlakukannya OJK, maka fungsi dan wewenang Bank Indonesia semakin sempit.Sementara tujuan tunggalnya tetap sama yaitu mencapai dan memelihara kestabilan nilai rupiah (Pasal 7). Memelihara kestabilan rupiah ini terhadap dua aspek yakni kestabilan rupiah terhadap harga barang dan kestabilan rupiah terhadap nilai tukar dengan mata uang negara asing (valas). Itulah tujuan tunggal Bank Indonesia (single objective). Dengan tujuan tunggal tersebut, Bank Indonesia selama ini mempunyai 3 (tiga) tugas yakni sektor moneter, sistem pembayaran dan sektor perbankan. Itulah tiga pilar penopang tujuan tunggal, namun dengan dilepaskannya sektor perbankan, kini tinggal dua sektor. Bila diibaratkan 3 pilar, maka 1 pilar telah patah.

OJK Sebagai lembaga independen, selain memiliki kewenangan dalam pengaturan dan pengawasan lembaga keuangan utamanya perbankan di Indonesia, juga memiliki kewenangan penyidikan. Kewenangan penyidikan dalam tugas pengawasan perbankan merupakan hal baru sejak Republik ini didirikan.Selain hal tersebut, yang merupakan hal baru adalah biaya operasional lembaga independen tersebut dapat dipungut dari lembaga keuangan yang diawasi termasuk perbankan. Ditengah-tengah eufhoria pemberantasan korupsi, Penjelasan POJK No.22/ POJK.01 / 2015 Tentang Penyidikan Tindak Pidana di Sektor Jasa Keuangan Pasal 4 ayat 1 - 225 Penjelasan POJK No.22/ POJK.01 / 2015 Tentang Penyidikan Tindak Pidana di Sektor Jasa Keuangan Pasal 5 ayat 1 226 Penjelasan POJK No.22/ POJK.01 / 2015 Tentang Penyidikan Tindak Pidana di Sektor Jasa Keuangan Pasal 6 ayat $1-2$ kondisi demikian tentu sangat rawan terhadap vested-interested dan "tuntutan kontra prestasi" diantara lembaga-lembaga tersebut. Selain itu, apabila perbankan dikenakan pungutan/fee tentu akan mendorong semakin tingginya biaya operasional perbankan dan bermuara terhadap peningkatan lending cost bagi perbankan secara keseluruhan. Pada akhirnya juga dapat menghambat pemberdayaan perekonomian nasional.

\section{SIMPULAN}

Lembaga OJK sebagai lembaga independen pengawas dan pengatur lembaga keuangan baik bank maupun non-bank di Indonesia akan mulai beroperasi per 1 Januari 2013, Kelembagaan baru tersebut berwenang untuk melakukan penyidikan, yang merupakan kewenangan baru lembaga pengawas perbankan yang selama ini tidak dimiliki oleh Bank Indonesia sebagai pengawas bank sebelumnya. Kiranya perlu dibuat aturan main yang jelas apa itu kewenangan penyidikan sehingga institusi yang diawasinya khususnya perbankan sebagai lembaga kepercayaan masyarakat tidak terkaget-kaget dengan kewenangan otoritas yang mengawasinya.

Pengaturan mengenai peranan OJK sebagai Penyidik dalam tindak pidana perbankan diatur dalam pasal 9 huruf (c) Undang-Undang No. 20 Tahun 2011 dan kewenangan OJK untuk melakukan Penyidikan Tindak Pidana di Sektor Jasa Keuangan dilakukan oleh Penyidik OJK diatur dalam pasal 2 ayat (2) Peraturan OJK Nomor 22/POJK.01/2015 Tentang Penyidikan Tindak Pidana di Sektor Jasa Keuangan yang menjadi landasan bagi OJK dalam melakukan penyidikan tindak pidana perbankan dalam bidang usaha yang berkaitan dengan kredit fiktif. Sehingga OJK melaksanakan fungsi penyelenggaraan sistem pengaturan dan pengawasan yang terintegrasi terhadap keseluruhan kegiatan di sektor jasa keuangan.

\section{DAFTAR PUSTAKA}

\section{Buku}

Arthesa,Andre dan Edia Handiman, Bank dan Lembaga Keuangan Bukan Bank, Jakarta: PT. Indeks Kelompok Gramedia, 2010.

Amiruddin dan Zainal Asikin, "Pengantar Metode Penelitian Hukum.", PT RajaGrafindo Persada, Jakarta, 2003.

C.S.T Kansil, "Pengantar Ilmu Hukum dan Tata Hukum Indonesia”, Jakarta:Balai Pustaka, 1989.

C.F.G. Sunaryati Hartono, "Penelitian Hukum di Indonesia Pada Akhir Abad Ke-2”, PT.Alumni, Bandung, 1994.

E.Utrecht dan Moh. Saleh Djindang, "Pengantar dalam Hukum Indonesia", Jakarta:PT Ichtiar Baru, Anggota IKAPI dan Penerbit Sinar Harapan, 1989.

Fuady, Munir, "Hukum tentang Lembaga Pembiayaan", Bandung:Citra Aditya Bakti, 1999.

Hermansyah, Hukum Perbankan Nasional Indonesia, Jakarta:Kencana, 2005.

Ibrahim, Johny, Teori dan Metode Penelitian Hukum Normatif. Malang: Bayumedia, 2006.

J.HAL. Fitzgerald, dalam Satjipto Rahardjo, "Ilmu Hukum”, Bandung:PT. Citra Aditya Bakti, 2000.

Kasmir, Bank dan Lembaga Keuangan Lainnya, Jakarta: RajawaliPress, 2008. 
Serlika Aprita, Kewenangan Otoritas Jasa Keuangan (OJK) Melakukan Penyidikan: Analisis Pasal 9 Huruf C Undang-Undang

Korespondensi: Safi', Konsep Pertanggung Jawaban Perbuatan Pemerintahan sebagai Sarana Mewujudkan Good Governance di Indonesia. Universitas Trunojoyo: Fakultas Hukum, Bagian Hukum Tata Negara, 2010.

Kusumaatmadja, Mochtar, "Pengantar Ilmu Hukum", Alumni, Bandung, 2000.

Meliala, Djaja S, Hukum Perdata dalam Prespektif BW, Bandung: Nuansa Aulia, 2012.

Muhammad, Abdulkadir dan Rilda Muniarti, Segi Hukum Lembaga Keuangan dan Pembiayaan, Edisi Revisi, Bandung:PT.Citra Aditya Bakti, 2004.

Marzuki, Peter Mahmud, Penelitian Hukum, Jakarta: Prenada Media,2005.

Marzuki, Peter Mahmud, "Penelitian Hukum Normatif", Kencana, Jakarta, 2010.

Rahardjo, Satjipto, "Ilmu Hukum” , Bandung:PT. Citra Aditya Bakti, 2000.

Rahardjo, Satjipto, Ilmu Hukum. Bandung: PT. Citra Aditya Bakti. Cetakan ketujuh, 2012.

Salim HS, Perkembangan Teori dalam Ilmu Hukum, Jakarta:Rajawali Pers, 2010.

Santoso, Tri Rudi, Mengenai Dunia Perbankan, Yogyakarta:ANDI, 1997.

Suhardi, Gunarto, Usaha Meningkatkan Kinerja dan Kepatuhan Perbankan di Indonesia, Yogyakarta:Universitas Atmajaya Yogyakarta, 2004.

Soekanto, Soerjono Soekanto, "Pengantar Penelitian Hukum", Jakarta:UI Press, 2007.

Soekanto, Soerjono dan Abdurrahman, "Metode Penelitian Hukum.”, Jakarta:Rineka Cipta, 1997.

Soekanto, Soerjono dan Sri Mamudji,"Penelitian Hukum Normatif Suatu Tinjauan Singkat", Jakarta:PT. Raja Grafindo Persada, 2002.

Situmorang, Victor, dan Jusuf Juhir, Aspek Hukum Pengawasan Melekat dalam Lingkungan Aparatur Pemerintah, Jakarta:Rineka Cipta,1994.

Usman, Rachmawadi, Aspek-Aspek Hukum Perbankan di Indonesia, Jakarta:Gramedia Pustaka Utama, 2001.

Waluyo, Bambang, Penelitian Hukum dalam Praktek. Jakarta: Sinar Grafika, 1996.

\section{Jurnal, Makalah dan Kamus}

Abimanyu, Anggito, Tantangan OJK, Ringkasan Makalah yang Disampaikan Kepada Pansel OJK, ditulis tanggal 08 April 2012.

Asmirawati, Nova, Catatan Singkat Terhadap UndangUndang Nomor 21 Tahun 2011 tentang Otoritas Jasa Keuangan, Jurnal Legislasi Indonesia, Vol.9. No.3, 2012.

Arsip Dokumen Dewan Perwakilan Rakyat Republik Indonesia,Risalah Sidang Pembentukan Otoritas Jasa Keuangan, Jakarta, 2010.
Patrik, Purwahid,"Peranan Perjanjian Baku dalam Masyarakat", Makalah, dalam seminar Standar Kontrak dalam Perjanjian Kredit, Surabaya, 11 Desember 1993.

Shadly, Hasan, dalam I Dewa Gede Atmadja, Penafsiran Konstitusi Dalam Rangka Sosialisasi Hukum, Sisi Pelaksanaan UUD 1945 Secara Murni dan Konsekuen, Pidato Pengenalan Guru Besar dalam bidang Ilmu Hukum Tata Negara Pada Fakultas Hiukum Universitas Udayana 10 April 1996.

Tim Penyusun Kamus Pusat Pembinaan dan Pengembangan Bahasa, Kamus Besar Bahasa Indonesia, Jakarta: Balai Pustaka, 1989.

\section{Peraturan Perundang-Undangan}

UU No 21 tahun 2011 tentang Otoritas Jasa Keuangan UU No 7 th 1992 sebagaimana diubah dengan UU No 10 th 1998 tentang Perbankan

UU No23 th 1999 sebagaimana diubah dengan UU No 3 th 2004 tentang Bank Indonesia

POJK No.22/ POJK.01 / 2015 Tentang Penyidikan

Tindak Pidana di Sektor Jasa Keuangan

\section{Website}

Pengertian Perlindungan Hukum, http://www.prasko.com/2011/02/pengertianperlindungan-hukum.html, diakses pada 14 Juni 2015. 